\title{
Environmental Threats to Child Health
}

\section{Çocuk Sağlığına Çevresel Tehditler}

\author{
Melda Çelik $^{1}$ (D) Kadriye Yurdakök ${ }^{2}$ (D)
}

${ }^{1}$ Hacettepe University, Department of Pediatrics, Department of Social Pediatrics, Ankara, Turkey

${ }^{2}$ Hacettepe University, Institute of Child Health, Department of Social Pediatrics, Ankara, Turkey

ORCID ID: M.Ç. 0000-0001-6093-2027; K.Y. 0000-0003-3672-3115

Citation/Atff: Celik M, Yurdakok K. Environmental threats to child health. Çocuk Dergisi - Journal of Child 2021;21(3):275-280.

https://doi.org/10.26650/jchild.2021.984802

\section{ABSTRACT}

Poor environmental conditions and pollution are known to contribute significantly to child deaths, diseases, and disability, particularly in the developing world. Environmental risks have major effects on child health and development from pre-conception to childhood and adolescence, sometimes persisting into adulthood. In the last 50 years, we have witnessed the spread of tens of thousands of newly discovered chemicals into the environment, leading to the detection of residual human-made chemicals in all animal and human tissues tested. Among these, the most common ones include phthalates, plastic products such as bisphenol $A$ (BPA), polychlorinated biphenyls (PCBs), lead, cadmium, dioxins, polycyclic aromatic hydrocarbons (PAH), solvents, pesticides, toxic substances in inhaled air (tobacco smoke, ozone, particulate matter), and chlorinated disinfection byproducts. Chronic exposure to low doses of these endocrine disrupting chemicals during sensitive periods may lead to developmental functional disorders that may not be observed with higher doses. In this text, the effects of these environmental threats on child health are reviewed.

Keywords: Effect, environment, chemicals, child health, pollution

Poor environmental conditions and pollution are known to contribute significantly to child deaths, diseases, and disability, particularly in the developing world, where approximately 14 million children die annually due to lack of healthy drinking water, poor hygiene, environmental pollution, prevalent diseases, and nutritional deficiencies, in addition to 3 million others who are afflicted with permanent disability. Multiple environmental factors may result in significant health problems and mostly irreversible effects in this age group.

Environmental risks have major effects on child health and development from pre-conception to childhood and adolescence, sometimes persisting into adulthood. öz

Olumsuz çevre koşulları ve kirlilik, özellikle gelişmekte olan ülkelerde çocuk ölümlerine, hastalıklara ve sakatlıklara önemli bir katkıda bulunmaktadır. Çevresel risklerin, çocukların sağı̆̆̆ ve gelişimi üzerinde prekonsepsiyonel, çocukluk ve ergenlikte ve bazen yetişkinliğe kadar devam eden önemli etkileri vardır. Son elli yıl içinde insanların geliştirdiği on binlerce yeni kimyasalın çevreye yayılması sonucu bütün hayvan ve insan dokularında doğal ve insan yapımı kimyasalların kalıntılarına rastlanmaktadır. Bunlardan en çok karşılaşılanlar fitalatlar, bisfenol A (BPA) gibi plastik ürünleri, poliklorine bifeniller (PKB), kurşun, civa, kadmiyum, dioksinler, polisiklik aromatik hidrokarbonlar (PAH), çözücüler, pestisitler, solunan havadaki toksik maddeler (tütün dumanı, ozon, partikülat maddeler) ve klorlanmış dezenfeksiyon yan ürünleridir. Bu kimyasalların çoğu doğal hormonların vücutta yapımı, salgılanması, taşınması, bağlanması veya yok edilmesini bozan "endokrin bozucu" etkiye sahiptir. Bu kimyasallara düşük dozlarda sürekli maruziyet yüksek dozlarda rastlanmayan gelişimsel fonksiyon bozukluklarına yol açmaktadır. Bu derlemede, bu çevresel tehditlerin çocuk sağlığına etkilerine değinilmiştir.

Anahtar Kelimeler: Etki, çevre, çocuk sağlığı, kimyasallar, kirlilik

Environment is the primary determinant of a child's future. Since fetal programming and early development in life may be influenced by environmental risk factors, early exposure may also affect health during adulthood.

Reduction of environmental risks may prevent up to 1 out of 4 deaths among children. In 2012 alone, 1.7 million children under 5 years of age were reported to die due to environmentrelated causes, including 570,000 deaths due to respiratory infections, 361,000 due to diarrhea, 270,000 due to diseases of the newborn, 200,000 due to malaria, and 200,000 due to inadvertent accidents (1). 
In the last 50 years, we have witnessed the spread of tens of thousands of newly discovered chemicals into the environment, leading to detection of residual human-made chemicals in all animal and human tissues tested. Among these, the most common ones include phthalates, plastic products such as bisphenol A (BPA), polychlorinated biphenyls (PCBs), lead, cadmium, dioxins, polycyclic aromatic hydrocarbons (PAH), solvents, pesticides, toxic substances in the inhaled air (tobacco smoke, ozone, particulate matter), and chlorinated disinfection byproducts (2). Most of these chemicals have "endocrine disruptive" effects that impair the production, release, transportation, binding and/or degradation of natural hormones, which have very important roles in development and maturation. Chronic exposure to low doses of these endocrine disrupting chemicals during sensitive periods may lead to developmental functional disorders that may not be observed with higher doses (3).

In contrast with the recent decrease in child deaths due to infectious diseases in the United States, a rise in chronic conditions is evident due to the contribution of environmental pollution, where a two-fold increase in asthma-related deaths, and increases in the incidences of leukemia, brain tumors, congenital developmental disorders, learning disorders, and developmental disorders of the genitalia and nervous system have been observed (4).

\section{Why are children more susceptible to environmental pollution?}

Accelerated industrialization is associated with an everincreasing risk of exposure to chemical pollutants among children, who represent the most susceptible age group to the effects of environmental pollutants. Children should not be conceived as small-sized adults, as childhood is a maturation step. Therefore, the effects on children can be carried over to other developmental stages and even to next generations. Since children experience a continuous state of growth and development starting from intra-uterine life, many environmental pollutants that do not cause significant harm in adults may be extremely hazardous for children. Pollutants spread all over the globe through air, water, soil, and food without barriers. A clear link has been found between lower socioeconomic status and residing in dangerously polluted areas, with a consequent increase in the risk of exposure to environmental hazards. Environment has different implications between children and adults. During the intra-uterine life, the initial environment in which the child strives, many toxic substances, particularly low molecular weight or fat-soluble compounds may readily be transferred through the placenta and lead to permanent damage. Lead, methyl mercury, ethyl alcohol, polychlorinated biphenyls, carbon monoxide, and nicotine in tobacco smoke are among these toxic substances (5).

During the dynamic developmental phase of children, cells grow, and organs and systems mature rapidly. Thus, the genetic material of the cell may be more susceptible to environmental pollutants during this rapid stage of growth. The nervous, respiratory, endocrine, reproductive, and immune systems are not fully maturated at birth, and their development continues after that stage. Due to immaturity of the blood-brain barrier, the central nervous system is exposed to an increased risk of adverse consequences. Furthermore, the skin of the newborn is extremely permeable, and time is required for complete maturity of the upper protective skin layer. The proportion of body surface area to body weight is 3-fold and 2-fold higher in newborns and older children compared to adults, respectively. Because of their proportionately higher body surface area than adults, children may absorb 2-3 times more through the skin than adults. Again, as compared to adults, children consume higher amounts and more various types of solid and liquid food per unit of bodyweight. For instance, milk and dairy product consumption is higher in children, who also have increased energy demands and exhibit differences in terms of the content of the nutrients consumed. Therefore, it follows that contamination of these nutrients may lead to an increased risk of exposure (4).

Since alveoli formation continues from birth to adolescence, the absorption surface also steadily expands. Many factors, including bacterial and viral infections, fungal spores, chemical air pollution (cigarette smoke, fuel combustion products, dry dung fuel or coal fume etc.) may adversely affect lung development and the structure of the respiratory airways. The growth of alveoli and pulmonary capillaries begin in the intra-uterine life and persist into 5-8 years of age. Oxygen consumption and requirement are also higher in children than in adults. Due to higher volumes of inhaled air in proportion to their bodyweight, children are more exposed to airborne pollutants such as ozone, particulate matter, and tobacco smoke. Since infants and children generally tend to inhale more through the mouth than the nose, the filtering effect of the nasal structures is attenuated. Narrower airways also mean that the duration of exposure to airborne pollutants is prolonged. A child playing in the street is more likely to be affected by exhaust gas as compared to an adult. Children spend the majority of their time outdoors and playing, which may increase the rate of respiration up to 10 -fold, and children may continue to play even if they experience shortness of breath. Children tend to spend even more time outdoors during the summer season, when ozone pollution is higher (1).

Infancy, on the other hand, is a period of more indoor activity. Household chemicals (cleaning materials, perfumes, dyes, pesticides etc.), eroded materials, smoke in the house (tobacco, etc.) and gases (spray deodorants, room deodorants etc.) may have a more pronounced and prolonged effect on these youngsters. As stated earlier, childhood is a period of more outdoor activity (street, school, daycare etc.) which may be associated with more marked exposure to pollutants found in these environments $(4,5)$.

Early behavioral characteristics during childhood may also have an impact on exposure to toxic substances. Prior to walking, children cannot distance themselves from hazardous environments even if they feel discomfort. Many evaporable 
chemicals heavier than air tend to accumulate close to the floor. Particularly during the period of crawling, children are more likely to be exposed to noxious chemicals and nitrates used against insects and pests, allowing the entry of many agents into the body via skin, respiratory system, or gastrointestinal tract (3).

Certain nutrients such as calcium are absorbed more rapidly than adults within the gastrointestinal tract of children, who continue to grow and develop after birth. As a consequence, certain toxic substances such as lead transported via the same mechanisms may compete with and replace calcium, leading to high rates of absorption. In addition, children tend to bring many items to their mouth to improve their familiarity with their surroundings, again increasing the risk of oral toxic substance intake (4).

In proportion to the rate of cell division, children also have a higher metabolic rate than adults. This increased metabolic demand is also associated with increased food intake, which may be contaminated with environmental pollutants. On the other hand, not only the levels of proteins that may bind to and neutralize noxious chemicals are lower in children, but also the metabolic and enzymatic processes are underdeveloped. Although the difference between early (fetal life and childhood) and adult life in terms of the ability to neutralize and dispose of toxic substances can sometimes have favorable effects, the reduced capacity for detoxification results in higher rates of exposure in most instances. During rapid embryogenic development, chromosomal changes due to chemical substances occur more frequently, resulting in congenital developmental disorders (6).

Tissue distribution of chemical substances differ according to the developmental stage in children. In newborns, most drugs exhibit distribution in many organs at high concentrations. For example, lead may accumulate at a higher rate in the bones of children $(4,6)$.

Since children have a long-life ahead with a consequently increased duration of exposure, tissue accumulation of many substances such as those in tobacco smoke or household chemicals may be associated with an increased risk of chronic diseases such as cancer and Parkinson's disease in the longer term (4).

\section{Fetal Effects}

Environmental effects begin much early than conception with the effects of chemicals on the parents. Pollutants may have an impact on the fetus via their adverse effects on the reproductive cells of the parents, or via placental transfer after accumulation in the maternal body. Studies have shown that environmental pollution may influence sperm quality and developing ova. Many environmental pollutants such as dichlorodiphenyltrichloroethane (DDT), banned in many countries after common use as a pesticide, polycyclic aromatic hydrocarbons (PAHs), polychlorinated biphenyls (PCBs), dioxins, diethylstilbestrol, tobacco smoke, pesticides, solvents, dyes, heavy metals (lead, cadmium, etc.), and phthalates may affect the reproductive system or cells of parents, potentially leading to dysfunction and several conditions in the fetus (2).

Dioxins and polychlorobiphenyls have embryotoxic effects. Maternal smoking is known to significantly increase the exposure of the fetus to carbon monoxide, hydrogen cyanide, cadmium, nicotine, and polycyclic aromatic hydrocarbons such as benzo-a-pyrene, all of which may be transferred readily from placenta to fetus $(2,5)$. Carbon monoxide impairs the oxygen and carbon dioxide carrying capacity of hemoglobin, with fetal concentrations being $10 \%$ to $15 \%$ higher than that of the mother $(2,5)$.

Intrauterine toxic effects can be detected via the examination of cord blood, meconium, and breastmilk. In one of the most comprehensive studies of cordon blood, the Environmental Working Group (EWG) detected a total of 287 different toxins in cordon blood obtained from 10 babies born in hospitals across the US, including heavy metals such as mercury, polyaromatic hydrocarbons (PAHs), persistent organic pollutants such as polybrominated dioxins and furane (PBDD/F), per- and polyfluoroalkylated substances (PFAS), chlorinated pesticides, polybrominated diphenyl ethers (PBDEs), polychlorinated naphthalenes, and polychlorinated biphenyls (PCBs) (7). The source of mercury is generally coal fuel plants, mercurycontaining products, and certain industrial procedures; this heavy metal tends to accumulate particularly in seafood, such as deep-sea fish. It has negative effects on brain development and function.

Other toxins that may affect intrauterine growth include the chlorinated pesticide metabolite dichlorodiphenyldichloroethylene (DDE), organochloride pesticides (e.g., chlorpyriphos), polycyclic aromatic hydrocarbons (PAHs) which are a cause of outdoor air pollution, particulate matter (PM) 10 or PM 2.5, carbon monoxide (CO), sulfur dioxide $\left(\mathrm{SO}_{2}\right)$, nitric oxide (NO), and ozone $\left(\mathrm{O}_{3}\right)(3)$. Maternal smoking is known to be associated with the birth of small for gestational age $(S G A)$ babies $(1,2)$. Exposure to polluted ambient air in the first trimester of pregnancy, particularly PM 2.5 and ozone, has been found to increase the risk of pre-eclampsia, gestational hypertension, premature delivery, and low birth weight in newborns (3).

The immediate surroundings in which the baby lives together with the mother following birth are generally indoors. Poor sanitation and ventilation as well as living in excessively crowded areas may worsen such conditions. Parental smoking has been associated with a two-fold increase in the incidence of pneumonia, bronchitis, and asthma among babies (5).

Soil Pollution: Along with water pollution, soil pollution contaminates the food sources and playgrounds of children. Many environmental pollutants may pass into breast milk, the primary source of nutrition for the newborn, and from breast milk to the body of the newborn. Many soil pollutants such as DDT and its derivatives, lead, cadmium, and mercury may readily pass onto breast milk. In this regard, fat-soluble pollutants tend to exhibit even more pronounced persistence 
in the body. Environmental pollutants may also pass to cow milk via plants, and may accumulate in the milk. Some antibiotics are administered at high doses to cows and therefore may be found in high concentrations in cow milk. Heavy pollutants such as strontium 90 that land onto soil via radioactive fallouts may be transferred to milk producing animals via plants, and from these to children consuming milk and its products. The strontium pollution in Scandinavian countries is monitored via concentration change in deciduous teeth of children (5).

Water Pollution: Nitrates from well water or other sources of water may cause methemoglobinemia in the first months of life, due to conversion of nitrates to nitrites under bacterial and metabolic effects in low gastric acidity. Water in superficial wells polluted by chemical fertilizers, and also by leakage from toilets, cattle-sheds, or stockrooms is rich in nitrates and bacteria that convert it to nitrite. In addition, nitrosamines formed by nitrates are carcinogenic substances. During the processing of the raw material of the rubber used in pacifiers, conversion to nitrosamines and nitrosatable substances is possible. Water pollution is also particularly important for babies fed with formulas. Both tap water and drinking water may result in the transmission of important biological infection agents to the baby $(4,5)$.

Food Pollution: There may be direct pollution of food, or indirect pollution from water and soil pollution. One of the chemical pollutants that may have access to the body of babies or children is cadmium from cigarettes. At the end of the 1940s, a disease named "itai-itai" was described that was associated with bone disease and renal dysfunction in individuals consuming rice polluted with cadmium in the river water used to water rice (2). Despite the protective effect of the placenta, small amounts of cadmium may be transferred to the fetus. Arsenic is a heavy metal that can be identified in water, and may lead to skin, lung, kidney, and urinary bladder cancers as well as discoloration of the skin with long term exposure. High concentrations of organic mercury, particularly in large sea fish has been found to adversely affect brain development in children in the case of regular consumption, while intrauterine exposure has been found to impair intelligence, speech, attention, and memory. Researchers have observed mental retardation in Iraqi children exposed to high levels of mercury $(2,3,8,9)$.

Air Pollution: Globally, 93\% of all children live in environments with air pollution levels above the limits defined by the WHO. Based on European Environment Agency data, 97.2\% of the urban populations in Turkey are exposed to hazardous levels of particulate matter (PM) in the air (1).

Indoor Air Pollution: Cigarette smoke, which contains approximately 3,800 different chemicals, is an important indoor air pollutant. Burning materials with high organic content such as wood or dung fuel may release a variety of gases and volatile organic compounds including $\mathrm{CO}, \mathrm{NO}_{2}, \mathrm{SO}_{2}$, particulate matter, benzene, benzo-a-pyrene, and formaldehyde that can pass through placenta with negative effects on the fetus (10,
11). These chemicals also have a pronounced effect on babies since they have a higher respiratory rate as compared to adults. Formaldehyde, benzene, and pesticides/insecticides commonly utilized in indoor settings are potential carcinogens (particularly with respect to hematological cancers). Volatile organic compounds, dyes, polishes, kerosene, thinners, newspapers, cleaning materials, photocopying chemicals, carpets, vinyl furnishing, deodorants, cigarettes, exhaust gases, and furniture produced from particle board may release these substances. Chronic exposure may lead to cancer as well as liver, kidney, and CNS injury $(2,3)$.

Outdoor Air Pollution: Pollution of the outdoor as well as indoor air is associated with an increased likelihood of invasion of the upper airways by causative infectious agents, due to the impairment of protective mechanisms. In developing countries, air pollution has a significant contributory role in approximately 4.2 million annual deaths caused by respiratory infections (1). Main pollutants in the outdoor air include particulate matter, ozone, $\mathrm{NO}_{2}, \mathrm{SO}_{2}$, and $\mathrm{CO}$. Ozone is formed by the reaction of hydrocarbons and nitric oxides released from motor vehicles, where sunlight plays a facilitatory role. Ozone increases the risk of asthma in children, impairs lung functions, and causes exercise induced dyspnea. These substances are known to cause adverse effects on the developing respiratory system, CVS, CNS, and urinary system in fetuses and children. Furthermore, childhood exposure has been associated with future occurrence of obesity and DM, and intrauterine exposure has been found to be linked with congenital cardiac disorders, low birth weight, prematurity, and SGA $(2,5,12)$.

Chemical Pollution: Heavy metals and persistent organic pollutants causing chemical pollution are more hazardous for children than for adults. Effects that occur during childhood may have life-long consequences. Sometimes, even chemicals used for therapeutic or other specific purposes (e.g., talc) may lead to important problems. Premature infants, newborns, and children of all age groups should be considered a special risk group in this regard.

The ban placed on the use of lead in gasoline and wall paints in the 1970 s and 1980 s resulted in significant reductions in blood lead levels in children. Today, since 2012, the reference value for blood lead levels in the US is $5 \mathrm{mcg} / \mathrm{dL}$ (13). The termination half-life of lead in tissues and bones is 10 years or longer. The absorption of lead per kg of bodyweight is higher in children, and nutrition poor in calcium and iron increases the absorption. Lead is hazardous for the CNS, blood cells, and kidneys, and high levels may lead to significant mental retardation, seizures, loss of consciousness, and coma. Also, exposure during intrauterine life or early childhood has been associated with attention deficit, hyperactivity, deficits in IQ, and learning difficulties $(3,4)$.

Persistent Organic Pollutants: These chemicals resistant to environmental degradation can remain unaltered for centuries in nature and may accumulate in the food chain. Most of these have already been detected in cord blood. Aldrin, dieldrin, 
chlordane, DDT, mirex, toxaphene, hexachlorobenzene, dioxins, PCBs, octachlorostyrene, heptachlor, benzopyrene, endrin, lead, and mercury are among the main persistent organic pollutants. Dioxins are byproducts in the production of certain organochlorides, burning of chloride-containing substances such as polyvinyl chloride (PVC), and bleaching of paper by chlorine, and are also released during volcanic eruptions or wildfire. Polybrominated dibenzodioxins and furans (PBBD/F) are present in brominated fire retardants, in addition to being final and byproducts of plastic production and combustion. They accumulate in the food chain with toxic effects on the developing endocrine system. Polychlorinated dibenzodioxins and furans (PCDD/F) are byproducts of PVC, industrial bleaching, and combustion. They are very toxic for the developing endocrine system and are known to be associated with cancer development. Organochlorine pesticides include DDT, chlordane, hexachlorobenzene, aldrin, and others. They persist in the environment for decades and accumulate in the food chain and adipose tissue. They are released from the adipose tissue in breastfeeding women, passing into breast milk. They may cause pollution in water resources, food, residential areas close to pest control applications, and playgrounds. They are associated with cancer, developmental disorders, and impairments in the reproductive and immune systems. Polybrominated diphenyl ethers (PBDEs) are used as flame retardants in computers and televisions, plastics, paper bleaching, the textile industry, and polyurethane furniture foam. They may accumulate in human tissues, negatively affecting brain development, sexual development, and thyroid functions, as well as causing liver and kidney injury. Polychlorinated biphenyls (PCBs) are a group of 209 chemicals utilized in industrial isolators, lubricants, thermal paper production, and as plasticizers. Their use was banned in 1976 in the US. They are endocrine disrupters, as well as being associated with liver and bile duct cancers and cognitive developmental disorders. In babies of mothers consuming fish polluted with PCBs, congenital anomalies and LBW may occur. Polychlorinated naphthalenes (PCNs) are found in wood preservation products, polishes, industrial lubricants, and can also be released by combustion of waste products. Per- and polyfluoroalkylated substances (PFAS) are present in teflon, fabric and carpet preservatives, as active ingredients of food packaging, and as degradation byproducts, representing a ubiquitous global pollutant. They accumulate in the environment and food chain and are associated with cancer and several birth anomalies $(3,7,14)$.

There are also various other chemical pollutants with endocrine disrupting effects in children. For instance, phthalates can be released from plastic containers to food, particularly when food is warmed in these containers or is wrapped with plastic films. They are present in intravenous fluid sets, body lotions, toys, cosmetic products, floor coverings, medical and consumer care products, and as elasticizing agents in hard polyvinyl chloride plastics (15). Intrauterine exposure to phthalates has been particularly linked with attention deficit hyperactivity disorder, as well as mental and sexual developmental disorders. Bisphenol $\mathbf{A}$ is also another endocrine disrupter used in plastics, and epoxy resins used in the inner lining of food cans, cash receipts, etc. (16). It is also found in plastic feeding bottles, pacifiers, toys, computers, mobile phones, and reusable food and drink containers. Exposure occurs through inhalation, ingestion, or skin absorption. Animal studies suggest that exposure to low dose BPA before and early after delivery can be associated with increased body weight and fat gain, alterations in male and female reproductive system development (e.g., cryptorchidism), changes in the structure of the mammary gland, breast and prostate cancer, type $2 \mathrm{DM}$, and precocious puberty $(2,3)$.

Although skin represents a natural barrier to the absorption of environmental pollutants, the skin characteristics of children and infants may be associated with increased absorption rates. Certain topical agents such as hexachlorophene represent a good example of this. Although initially, the use of soap and other cleaning products containing hexachlorophene was not associated with any apparent toxic effects, sudden deaths have been reported in France among babies using hexachlorophenecontaining talc (17). Immature epidermal barrier functions among premature babies resulting in facilitated absorption of this chemical through the humid diaper region is the most important factor. Lindane ( $\gamma$-benzene hydrochloride) resulted in a 17-fold increase in levels in premature babies after topical application $(3,4)$, indicating the significance of the barrier function of the skin (18).

Informed Consent: Written consent was obtained from the participants.

Peer Review: Externally peer-reviewed.

Author Contributions: Data Acquisition- M.K.; Data Analysis/ Interpretation- K.Y.; Drafting Manuscript- M.K.; Critical Revision of Manuscript- K.Y.; Final Approval and Accountability- M.K., K.Y.

Conflict of Interest: Authors declared no conflict of interest.

Financial Disclosure: Authors declared no financial support.

Bilgilendirilmiş Onam: Katılımcılardan bilgilendirilmiş onam alınmıştır.

Hakem Değerlendirmesi: Dış bağımsız.

Yazar Katkıları: Veri Toplama- M.K.; Veri Analizi/Yorumlama- K.Y.; Yazı Taslağı- M.K.; İçeriğin Eleştirel İncelemesi- K.Y.; Son Onay ve SorumlulukM.K., K.Y.

Çıkar Çatışması: Yazarlar çıkar çatı̧̧ması beyan etmemişlerdir.

Finansal Destek: Yazarlar finansal destek beyan etmemişlerdir.

\section{REFERENCES}

1. Environmental health. World Health Organization (WHO). https:// www.who.int/health-topics/environmental-health\#tab=tab_1. (Date of access: 03.07.2021).

2. Yurdakök K. Environmental Pollution and Fetus. In Yurdakök Pediatri. Vol 1. Part 2-Social Pediatrics. Ankara: Güneş Books 2018; 209-16. 
3. Güler Ç. Child and Environment. In: Yurdakök Pediatri. Vol 1. Part 2- Social Pediatrics. Ankara: Güneş Books 2018;182-209.

4. Güler Ç. Child, Environment and Environmental Pollution. Katkı Pediatrics Journal 2008;3:279-362.

5. Güler Ç, Çobanoğlu Z. Child and Environment. Vol. 1., Ankara: Aydoğdu Publishing 1994.

6. Güler Ç. Çocuk Çevre Sağlığı. Güler Ç. Environmental Pollution and Child, Ankara: Yazıt Publishing 2011:63-71.

7. Body-burden: The Pollution in Newborns. Environmental Working Group, July 14, 2005. https://www.ewg.org/research/bodyburden-pollution-newborns. (Date of access: 18.12.2020)

8. Bakir F, Rustam H, Tikriti S, Al-Damluji SF, Shihristani H. Clinical and epidemiological aspects of methylmercury poisoning. Postgrad Med J 1980;56(651):1-10.

9. Myers GJ, Davidson PW. Does methylmercury have a role in causing developmental disabilities in children? Environ Health Perspect 2000;108(Suppl 3):413-20.

10. Leonardi-Bee J, Smyth A, Britton J, Coleman T. Environmental tobacco smoke and fetal health: systematic review and metaanalysis. Arch Dis Child Fetal Neonatal Ed 2008;93:F351-F361.

11. Choi H, Jedrychowski W, Spengler J, et al. International studies of prenatal exposure to polycyclic aromatic hydrocarbons and fetal growth. Environ Health Perspect 2006;114:1744-50.
12. Lee PC, Roberts JM, Catov JM, Talbott EO, Ritz B. First trimester exposure to ambient air pollution, pregnancy complications and adverse birth outcomes in Allegheny County, PA. Matern Child Health J 2013;17:545-55.

13. Advisory Committee on Childhood Lead Poisoning Prevention of the Centers for Disease Control and Prevention 2012. Low level Lead exposure harms children: a renewed call for primary prevention. US Department of Health and Human Services.

14. Ou Y, Zeng X, Lin S, Bloom MS, Han F, Xiao X, Wang H, Matala R, Li X, Qu Y, Nie Z, Dong G, Liu X. Gestational exposure to perfluoroalkyl substances and congenital heart defects: A nested case-control pilot study. Environ Int 2021;154:106567.

15. Sathyanarayana S. Phthalates and children's health. Curr Probl Pediatr Adolesc Health Care 2008;38:34-49.

16. Rudel RA, Gray JM, Engel CL, Rawsthorne TW, Dodson RE, Ackerman $J M$, et al Food packaging and bisphenol A and bis(2-ethyhexyl) phthalate exposure: findings from a dietary intervention. Environ Health Perspect 2011;119:914-20.

17. Martin-Bouyer G, Toga M, Lebreton R, Stolley P, Lockhart J. Outbreak of accidental hexachlorophene poisoning in France. The Lancet 319(8263), 91-5.

18. Pramanik AK, Hansen RC. Transcutaneous gamma benzene hexachloride absorption and toxicity in infants and children. Arch Dermatol 1979;115(10):1224-5. 